\title{
Race の異なるいもち病菌に対する
}

\section{イネ品種の細胞反応の差異}

\author{
大 畑 貫 一* . 後藤 和 夫**.高坂 淖 爾*
}

Kan-ichi $\widehat{O}_{\text {HATA, Kazuo Goto and Takuji KōzAKa }}$ : Observations on the reaction of rice cells to the infection of different races of Piricularia oryzae.

\section{1. 緒言}

病原菌の侵入初期飞郝仔る奇主細胞の生死を明らか にすることは抵抗機作の解明, 病原菌の分泌する毒素 の役割等の解明に重要な足場を与兄る。さて,いもち 病菌の侵入にさいして抵抗性品種では細胞の急激な変 性壊死がみられることはすで鋳方らう), 河村らすをは じめ多くの研究者によつて詳しく報告されているが, 罹病的な場合の被侵入細胞の生死については, 伊藤・ 坂本 ${ }^{6)}$, 鐙谷 ${ }^{1)}$ の観察があるに過ぎない。伊藤らは罹 病性品種(初紫) 葉鞘接種し, 被侵入細胞拈よび隣接 細胞の原形質分離能を調査した結果, 接種後 $24 \sim 48$ 時 間では被侵入細胞は原形質分離能をるつていること, また隣接細胞は菌の直接の侵入をうけるに先だつて生 きてはいるが，何らかの原因で害作用を受けているこ とを観察し，「組織内の菌糸のまん延には侵害を受け た寄主細胞の生活状態，したがつてまた侵入しきたれ る菌糸汇対する奇主細胞原形質の反応によつて条件づ けられるごとく考光られる」との卓見を述べたが,その 後これに関した報告をみない。最近鐙谷) は被侵入細 胞の原形質分離能等を多数の品種について観察し, 寄 主細胞が少しでも長く生きていることが抵抗性の発現 に重要な条件であろうと報じた。著者ら 3 はさきに抵 抗性の異なる品種に病原力の異なる菌株を相互接種す ると抵抗反応を示さない組み合わせでは被侵入細胞は 菌の侵入後相当長時間原形質分離能をもち，生きてい ると考兄られることを略報したが，本報はそれにさら にその後実施された成績を加えたるのである。

本研究を実施するにあたり，種及有益な助言をいた だいた鈴木直治技官，貴重な文献を貸与いただいた高 橋喜夫教授ならびに顕微鏡写真の撮影について御指導 いただいた梶原技官に梁甚な謝意を表する。

\footnotetext{
* 農林省農業技術研究所

** 農林省農林水産技術会議
}

\section{2. いもち病菌の侵入程度と寄主細胞の生死}

葉䩗接種して所定時間ごとに裏面表皮のストリップ を作り，原形質分離の有無で寄主細胞の生死を判定し た。

供試菌としてP 2 菌株を用いイネ品種はこの菌株に 対して抵抗性を示す荔支江と，罹病性を示す愛知旭を

第 1 表 菌の侵入程度と寄主細胞の生死

\begin{tabular}{|c|c|c|c|c|c|c|}
\hline \multirow{2}{*}{$\begin{array}{l}\text { 接種後 } \\
\text { 経過時 } \\
\text { 間 }\end{array}$} & \multirow{2}{*}{ 品種 } & \multirow{2}{*}{\begin{tabular}{|l} 
侵入菌 \\
系の伸 \\
展度
\end{tabular}} & \multirow{2}{*}{$\begin{array}{l}\text { 調 查 } \\
\text { 細胞数 }\end{array}$} & \multirow{2}{*}{$\begin{array}{l}\text { 変 } \\
\text { 細胞数 } \\
\end{array}$} & \multicolumn{2}{|c|}{$\begin{array}{l}\text { 原形質分離能 } \\
\text { 消失率 }(\%) \text { ) }\end{array}$} \\
\hline & & & & & $\begin{array}{l}\text { 被侵入 } \\
\text { 細 胞 }\end{array}$ & 隣接細胞 \\
\hline \multirow{3}{*}{ 12時間 } & 荔支江 & $\begin{array}{l}0.5 \\
1\end{array}$ & $\begin{array}{l}6 \\
1\end{array}$ & $\begin{array}{l}0 \\
0\end{array}$ & $\begin{array}{l}0 \\
0\end{array}$ & $\begin{array}{l}0 \\
0\end{array}$ \\
\hline & & & & & & \\
\hline & 愛知旭 & 0.5 & 15 & 0 & 0 & 0 \\
\hline & & & & & & \\
\hline \multirow{5}{*}{ 18時間 } & 䒴支汀 & 0.5 & 30 & 16 & 73 & 0 \\
\hline & 㹢双忚 & 1 & 15 & 11 & 100 & 0 \\
\hline & & 0.5 & 27 & 5 & 11 & 0 \\
\hline & 愛知旭 & 1 & 12 & 1 & 8 & 0 \\
\hline & & 2 & 1 & 0 & 0 & 0 \\
\hline \multirow{7}{*}{ 24時間 } & & 0.5 & 37 & 22 & 90 & 8 \\
\hline & 荔支江 & 1 & 25 & 16 & 95 & 9 \\
\hline & & 2 & 4 & 0 & 80 & 0 \\
\hline & & 0.5 & 19 & 5 & 53 & 2 \\
\hline & & 1 & 17 & 4 & 23 & 6 \\
\hline & 愛知旭 & 2 & 8 & 0 & 12 & 0 \\
\hline & & 3 & 15 & 1 & 33 & 2 \\
\hline \multirow{11}{*}{ 44時間 } & & 0.5 & 22 & 18 & 100 & 8 \\
\hline & 荔支江 & 1 & 14 & 8 & 100 & 6 \\
\hline & & 2 & 2 & 2 & 100 & 0 \\
\hline & & 0.5 & 10 & 9 & 90 & 2 \\
\hline & & 1 & 11 & 9 & 73 & 0 \\
\hline & & 2 & 4 & 4 & 100 & 0 \\
\hline & 爱知加 & 3 & 8 & 5 & 100 & 19 \\
\hline & 这㚘回 & 4 & 7 & 5 & 100 & 27 \\
\hline & & 5 & 2 & 1 & 100 & 62 \\
\hline & & 6 & 1 & 1 & 100 & 63 \\
\hline & & 7 & 1 & 1 & 100 & 55 \\
\hline
\end{tabular}


用いた。温室内で栽培したイネの頂葉展開度のそろつ た主稈を選び，その第 3 葉鞘（上から）にイースト培 地上で形成された胞子の浮遊液を接種した。接種法は 高橋 ${ }^{22}$ に準じ, 胞子濃度は 150 倍 1 視野当たり $1 \sim 2$ コとした。接種後 $26^{\circ} \mathrm{C}$ の定温器内に打いて 12,18 , 24，44時間目に取り出し，葉鞘裏面表皮をかみそりで はぎとり， $0.8 \mathrm{M} \mathrm{KNO}_{3}$ によつて原形質分離をおこ させ, 侵入菌糸の伸展度 (高橋基準), 被侵入細胞な らびにその隣接細胞の原形質分離の有無を調べた。1 回の観察には 3 葉鞘を用いたが，各回の調查個所数は 一定しなかつた。

結果は第 1 表に, また代表的事例を Plate I に示し た。接種後 12 時間目には両品種とも侵入菌糸の伸展 度は約 0.5 位で被侵入細胞, その隣接細胞にも变質は 見られず，すべて原形質分離能をもつていた。18時間 目には侵入菌糸の伸展度は荔支江では $0.5 \sim 1.0$, 愛知 旭では 0.5 2 で両品種とも被侵入細胞のあるもので は黄変果粒化が現われ始めたが，その割合は荔支江で 著しく高かつた。また荔支江では被侵入細胞の約 70 \%以上が原形質分離能を失つていたが愛知旭ではこれ が $10 \%$ 前後にすぎなかつた。この時期まではな报両 品種とも隣接細胞の原形質分離能は失われていなかつ た。24時間目には荔支汇での侵入菌糸の伸展度はほと んど前回と变わらず，まれに伸展度 2 のものがみられ た。いずれの伸展度のものでも被侵入細胞の大部分が 原形質分離能を失い，また伸展度の小さい被侵入細胞 の隣接細胞は約 $10 \%$ が原形質分離能を失つていた。 愛知旭では侵入菌糸の伸展度が 3 に達するものも多か つたが，いずれの伸展度の被侵入細胞でも原形質分離 能消失率はほぼ 50 \%以下で隣接細胞のそれも荔支江 よりも低かつた。44時間目には荔支江では菌糸はすで に生長を停止し，被侵入細胞のすべてが变質して原形 質分離能もなかつた。愛知旭では引き続いて菌杀が伸 長し，伸展度 7 に達したものがあり，被侵入細胞のほ とんどすべてが原形質分離能を失つていた。隣接細胞 の原形質分離能消失率もこの時期には愛知旭が荔支江 よりも高く, 24 時間目までの結果とは逆になつてい た。これは愛知旭では侵入菌糸はすでに数細胞を侵す ほど伸長して隣接細胞への影響がさらに強くなつてい るのに反し, 荔支江では 24 時間目以降侵入菌糸はほ とんど伸長せず，菌と寄主細胞との闘争はすでに終わ り，その後の周辺細胞への影響がなくなつたためであ ろち。

以上を要約すると荔支江の被侵入細胞の死は侵入早 期にみられ侵入菌糸の伸長も早期に停止するが, 愛知
旭では第 1 次被侵入細胞（附着器から直接侵入を受け た細胞）は比較的遅くまで生きて和り，菌糸は引き続 いて伸長し隣接細胞に侵入する。隣接細胞の死孔抵抗 性品種では早く起きるが小範囲に限られるのに反し, 羅病性品種では遅く現われる。後期には 2 次被侵入細 胞数の増加につれて死細胞数は多くなる。

被侵入細胞の变質過程をみると, 原形質流動の激化 $\longrightarrow$ \゙゙ラン運動の出現—原形質のゲル化の過程が 観察された。原形質流動の激化は侵入のごく初期にみ られたが, 出現細胞数が少なく, その品種間差異を明 らかにすることができなかつた。原形質内のブラウン 運動は接種後18時間目頃から一部の被侵入細胞で観察 され，荔支江でいくぶん出現率が高いようであつた。 また接種後 24 時間目には荔支江では被侵入細胞のブラ ウン運動はすでに停止し，隣接細胞にこれがみられた が，愛知旭では被侵入細胞にみられる例が割合に多か つた。接種後 44 時間目にはすでに両品種ともゲル化 が進み,ブラウン運動のみられる細胞はきわめて少な くなつた。一方隣接細胞の死は被侵入細胞が軽い変質 を起こし，しかも菌糸がある程度伸びているような場 合に多くみられた。

\section{3. 被侵入細胞の変啠と菌の生死}

被侵入細胞内の菌糸の生死と㟢主細胞の死との時間 的な関係を知るため次のような実験を行なつた。

葉鞘接種して $26^{\circ} \mathrm{C}$ に 24 時間和いた後, 常法によ り葉鞘裏面表皮のストリップを作り, 被侵入細胞の状 態を撮影し，再びこれを湿室に入れて $26^{\circ} \mathrm{C} て ゙ 20$ 時 間和いたのち, 前回と同じ個所を原形質分離処理を行 なつて撮影し, 細胞の変性, 菌糸の伸長の状況を比較 して菌执よび細胞の生死を判断した。

結果は第 2 表に, 代表的事例を Plate II に示した。 荔支江では变質細胞内の菌糸の多くは接種後 24 時間 目ですでに形態的にも異常を呈し，その後伸長がみら れなかつた。しかし接種後 24 時間目に比較的軽い变 質を起こしていた細胞，あるいはブラウン運動をして いた細胞内の菌糸は 44 時間目までにさらに伸長した 例が数例あつた。もちろんこの時期には被侵入細胞は 死滅していた。愛知旭でも24時間目にひどく変質して いた細胞内の菌糸はその後伸長しないが，原形質分離 がみられた細胞内の菌杀は明らかにその後伸長してい た。菌糸の伸長の有無から菌の生死を判断することは 必ずしも正確な方法ではないが, 同一菌糸の形態的変 化をも合わせて観察すると, 荔支江では変質細胞内の 菌糸が接種後 24 時間目までに大部分死んでいると考 
第 2 表 被侵入細胞の变質と菌の生死

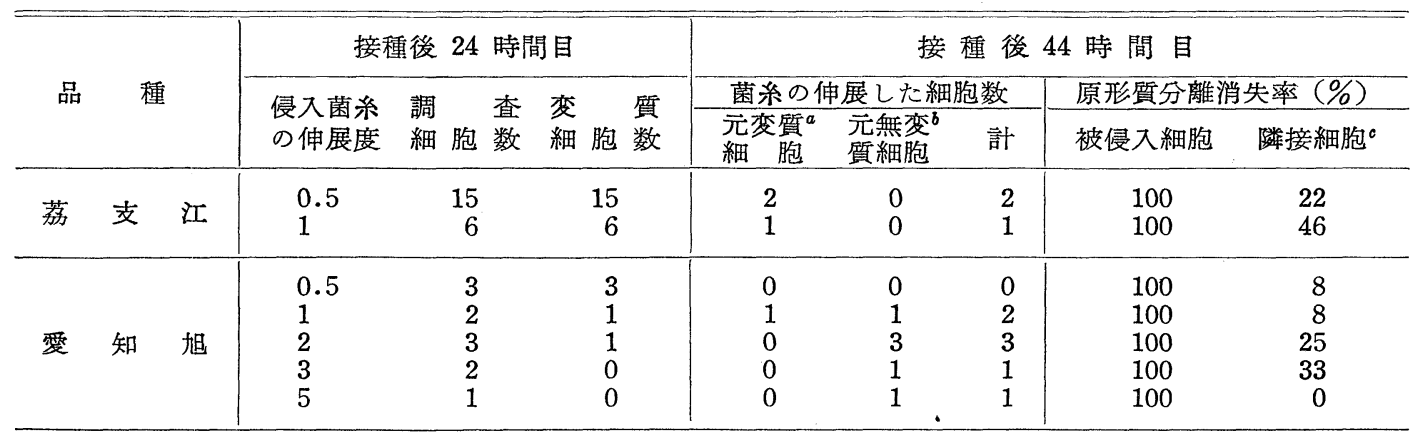

$a \quad$ 接種後 24 時間目に変質していた細胞

b 接種後 24 時間目に変質していなかつた細胞

・菌糸がまん延し隣りの附着器から伸びた菌糸と錯綜して調査し得ない細胞は除外した

第 3 表 被侵入細胞ならびに隣接細胞の原形質分離

\begin{tabular}{|c|c|c|c|c|c|c|c|}
\hline \multirow{2}{*}{$\begin{array}{l}\text { 接 種 後 } \\
\text { 経過時間 }\end{array}$} & \multirow{2}{*}{ 品 種 } & \multirow{2}{*}{ 菌 株 } & \multirow{2}{*}{$\begin{array}{l}\text { 調 查 } \\
\text { 細胞数 }\end{array}$} & \multirow{2}{*}{$\begin{array}{l}\text { 侵入菌糸 } \\
\text { の伸展度 }\end{array}$} & \multirow{2}{*}{$\begin{array}{c}\text { 变質率 } \\
(\%)\end{array}$} & \multicolumn{2}{|c|}{ 原形質分離能消失率 (\%) } \\
\hline & & & & & & 被侵入細胞 & 隣接細胞 \\
\hline \multirow{2}{*}{24 時 間 } & 荔支江 & $\begin{array}{c}\text { P 2 } \\
53-33\end{array}$ & $\begin{array}{l}39 \\
39\end{array}$ & $\begin{array}{l}1.06 \\
2.14\end{array}$ & $\begin{array}{r}7 \\
18\end{array}$ & $\begin{array}{l}85 \\
52\end{array}$ & $\begin{array}{r}6 \\
12\end{array}$ \\
\hline & 愛知旭 & $\begin{array}{c}\mathrm{P} 2 \\
53-33\end{array}$ & $\begin{array}{l}40 \\
39\end{array}$ & $\begin{array}{l}1.63 \\
2.26\end{array}$ & $\begin{array}{l}48 \\
13\end{array}$ & $\begin{array}{l}67 \\
22\end{array}$ & $\begin{array}{l}7 \\
0\end{array}$ \\
\hline \multirow{2}{*}{40 時 間 } & 荔支江 & $\begin{array}{c}\text { P } 2 \\
53-33\end{array}$ & $\begin{array}{l}120 \\
106\end{array}$ & $\begin{array}{l}0.92 \\
2.75\end{array}$ & $\begin{array}{l}87 \\
50\end{array}$ & $\begin{array}{l}88 \\
81\end{array}$ & $\begin{array}{l}16 \\
36\end{array}$ \\
\hline & 愛知旭 & $\begin{array}{c}\text { P 2 } \\
53-33\end{array}$ & $\begin{array}{l}106 \\
109\end{array}$ & $\begin{array}{l}2.31 \\
3.22\end{array}$ & $\begin{array}{l}41 \\
24\end{array}$ & $\begin{array}{l}82 \\
76\end{array}$ & $\begin{array}{l}21 \\
13\end{array}$ \\
\hline
\end{tabular}

えられる。しかしこの時期までに変質の軽い場合，あ るいはブラウン運動をしていた細胞内では菌糸がその 後伸長した場合が観察されたことから，扣そらく荔支 江の被侵入細胞内に和ける菌系の死は寄主細胞の死よ りも遅れるよ5に推察される。愛知旭の場合は侵入初 期にひどく細胞変質がみられた場合を除いてはすべて 菌糸の伸長が引き続いてみられたから, 細胞の死が起 こつても明らかに菌禾は生きていると考えられる。

\section{4. 病原力の異なつた菌株を用いた ときの寄主細胞反応の変化}

いもち病菌には race の存在が明らかとなつたの で)異なる raceに属する菌株を接種して寄主細胞の生 死ならびに 2,3 の生理的反応を組織化学的に調べた。

\section{（a） 菌の侵入と寄主細胞の生死}

供試品種は 2 と同じである。供試菌は P 2 菌（後藤 ら4)の分類では $\mathrm{N}$ race 群に属し, 日本稻のみに病原 性がある）和よび 53-33 菌（C race 群に属し，支那 稲，日本稻に病原性がある ${ }^{4}$ ) である。両菌株を噴霧 接種した場合の供試品種の反応は次のようである。イ

\begin{tabular}{|c|c|c|c|}
\hline \multirow{2}{*}{ 菌株 } & \multicolumn{2}{|c|}{ 品種の反応 } & \multirow{4}{*}{$\begin{array}{l}\mathrm{R}: \text { Resistant } \\
\mathrm{S}: \text { Susceptible } \\
\mathrm{M}: \text { Moderate }\end{array}$} \\
\hline & 荔支江 & 愛知旭 & \\
\hline $\mathrm{P} 2$ & $\mathrm{R}\left(\begin{array}{c}\text { まれに少数 } \\
\text { 個体にM }\end{array}\right)$ & $\mathrm{S}$ & \\
\hline $53-33$ & $S \sim M$ & $\mathrm{~S}$ & \\
\hline
\end{tabular}

ネは戸外で慣行法によつて栽培し，穂孕期に生育のそ ろつた 1 次荎の止葉葉鞘を供試した。供試胞子はあら かじめ旭 1 号苗に噴雺接種し, その病斑上に形成され たものである。接種方法並びに寄主細胞の生死の判定 は 2 に準じた。1 1 区の供試葉鞘は 4 本で, 調査は接種 後 24 時間目々 40 時間目の 2 回行なつた。

結果は第 3 表に示す。接種後 24 時間目では荔支江 に 53-33 菌（病原力強）を接種した場合, 被侵入細胞 の原形質分離能の消失率は P2 菌（病原力弱）を接種 した場合に比べて著しく低かつた。愛知旭でも同様の 傾向が明らかにみられた。隣接細胞の原形質分離能消 失率は荔支江では P 2 菌接種区が 53-33 菌接種区よ り低いが，愛知旭では逆に P 2 菌接種区が高かつた。 接種後 40 時間目になると原形質分離能の消失率は高 
くなるが，全般的にみて 24 時間目の傾向と一致して いた。

すなわち，一般には抵抗性とされている品種でも病 原力の強い菌株を接種すると侵入菌糸の伸展度は増大 し，被侵入細胞はより遅くまで生きて和り，抵抗性の 弱い品種と類似した反応を示す。また抵抗性の弱い愛 知旭は病原力の強い菌株を接種することによつて前項 に記述した抵抗性を示さない場合の反応が一層顕著と なる。

隣接細胞の死は荔支江では P 2 接種区すなわち抵抗 的な場合飞少なく，愛知旭では $53-33$ 接種区すなわち 羅病的な場合に少なかつた。この結果は一見相反して いる。しかし最も抵抗的な場合(荔支江に P 2 菌接種) には菌の侵入による細胞の死は被侵入細胞に限られる し, 最も罹病的な場合（愛知旭飞 53-33 菌接種）に は隣接細胞はもちろん被侵入細胞も生きていること, また一方, 隣接細胞の死は既述の上うに被侵入細胞が ゆるやかな抵抗反応（軽い変質がみられる）をしなが ら菌糸がある程度伸びている場合に観察されることを 合わせ考えると, 接種後 40 時間位までは強抵抗, 強罹 病性の場合に隣接細胞の死はかえつてすくないとみら れるので上記の結果は当然のことであろう。

\section{（b） 菌の侵入之寄主細胞の 2,3 の生理的変化}

病原力の異なる菌株を接種した場合の各品種の TT C 還元作用, nadi 試薬拉よび phloroglucine-HCl K よる呈色反応の変化を調べた。調査方法は次のようで ある。

TTC 還元作用: 常法によつて接種し 48 時間定温 に保つた葉鞘を $2 \mathrm{~cm}$ に切り,ツンベルグ管内で $0.5 \%$ glucose $1.5 \mathrm{ml}, 10^{-2} \mathrm{M}$ TTC (triphenyltetrazolium chloride) $1.5 \mathrm{ml}$ を加光て $30^{\circ} \mathrm{C}$ で 2.5 時間真空状態 で反応させた後鏡検した。

nadi 試薬による呈色反応：試薬の調製は $\operatorname{Lison}^{8)}$ の 方法に準じた。接種後 48 時間目の葉䩗裏面表皮を $\mathrm{pH}$ 8.4 で 20 分間反応させて鏡検した。な招 nadi 試薬に よる呈色物質の推定は鈴木 ${ }^{11}$ の方法によつた。

phloroglucine-HCl に上る呈色反応：接種後 48 時

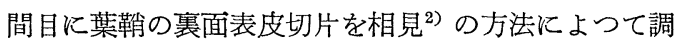
べた。結果は次のようである。

TTC 還元作用: 荔支江に P2 菌接種区では, すで に変質していた被侵入細胞に反応が認められることは まれで，その隣接細胞に反応が強く現われている例が 多かつた。53-33 菌接種区では被侵入細胞に微弱な反 応が残つていることがあつたが，一般には反応は認め られなかつた。隣接細胞ではわずかに強く現われるこ
とがあつた。愛知旭に P2 菌接種区の侵入初期では変 質のない細胞あるいは隣接細胞で比較的強い反応が認 められた。愛知旭に 53-33 菌接種区では被侵入細胞飞 は反応はなく，その隣接細胞でも反応は微弱であつ た。以上を前項の結果と総合すると，抵抗反応によつ てすでに変質した 細胞には脱水素酵素の 反応はない が，その隣接細胞で比較的強い反応が現われる傾向が ある。また抵抗反応が弱く，変質がみられない被侵入 細胞に弱い反応があるが，菌紋があん延した細胞では これが消失する。このような細胞の隣接細胞では反応 がわずかに強くなる場合がある。

nađi 試薬による呈色反応 : 荔支江に P2 菌接種区 では変質被侵入細胞のみに鮮明な反応が現われた。 53 -33 菌接種区では変質被侵入細胞には反応があつた が, 菌糸がまん延し，変質のみられない細胞には反応 はみられなかつた。愛知旭でも同様に被侵入細胞ある いはその隣接細胞が変質している場合のみ反応が現わ れた。以上要するに nadi 試薬による呈色反応は抵抗 反応によつて奇主細胞が変質している場合にのみ陽性 で, 菌糸がまん延しても変質の及られない場合には陰 性である。本試薬に呈色する物質は $\mathrm{KCN}$ 処理あるい は熱処理しても脱色しないので, 鈴木 ${ }^{11)}$ が指摘してい るようにポリフェノールあるいはキノン性の物質であ ろら。

phloroglucine-HCl による呈色反応: 荔支江に P 2 菌接種区では変質細胞の細胞膜が淡紅色〜紅色に染ま り，53-33 菌接種区でも変質細胞にのみ同様の呈色が みられた。愛知旭に P 2 菌接種区でも变質細胞では細 胞膜がわずかに呈色したが，53-33 菌接種区では呈色 する例はまれであつた。すなわち抵抗反応によつて細 胞が変質している場合にのみ反応は陽性である。

\section{5. 論議}

以上の結果を総合すると，一般にきわめて罹病的な 場合には被侵入細胞の死は細胞内に菌糸が相当発育し たのちに起こり，活物寄生的性格をもち褐変果粒化な どもみられないが，抵抗性を示すほど被侵入細胞の死 は早まる。また菌糸の死は寄主細胞の死の後に起きる ように推察される。これを模式的に示すと Fig. 1 の ようになる。

抵抗性品種における被侵入細胞の急激な死は既往の 観察結果 ${ }^{5,7)}$ と一致する。また䍜病性品種に抢ける被 侵入細胞の死の遅延は伊藤・坂本 $\left.{ }^{6}\right)$ の結果とよく一致 する。鐙谷) はいずれの品種でも菌禾の伸長した細胞 は原形質分離能を失い，また罹病性品種では細胞に外 
観的変化がなくて原形質分離能を失い，抵抗性品種で は褐変果粒化等の変化のある時にこれを失つているこ とを報じている。この点著者らの結果と相違する。し かし同氏の観察は拈もに接種後 48 時間以降を対象と して扣り, 著者らの観察とは時間的に違つているこ と, また著者らの観察でも接種後 44 時間目位の第 2 次被侵入細胞では鐙谷の観察と一致するから，両者の 結果は本質的に異なるものではないようにも思われ る。最近富樫ら ${ }^{16)}$ はピリクラリン処理葉䩗に拈いて罹 病的な葉鞘細胞は菌の侵入初期に原形質分離能を保持 していることが多く, 抵抗性を示すときに原形質分離 能を失つていると報じているが，これは著者らの観察 とよく一致している。

抵抗反応が現われる時の寄主細胞の死と細胞内菌糸 の死との時間的関係については既往の報告がなく，著 者らの観察数も少数すぎるから更に検討が必要である らが, 細胞変質がややゆるやかな場合では細胞は死ん でもその中の菌糸はなおしばらくの間伸長した例から みると, 寄主細胞の死が菌杀の死よりも先行するよう に考えられる。もしこの考光方が普遍的にいもら病に ついて成立するとすれば, 既述のように抵抗反応が侵 入のきわめて初期に現われることからして, 被侵入細 胞では過敏感死，ひいては病菌の死という過敏抵抗が 成立するとみられないこともない。このうち過敏感死 などで生ずる 細胞内褐変物質生成については 鈴木ら

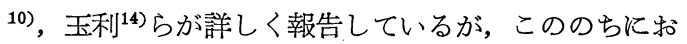
こる菌の死については細胞变質の過程に拉いていもち 病菌に特異的なある種の抗菌性物質の生成などの仮定 を考慮しなければならないであろう。この意味では植 原 ${ }^{18)}$ の報じた phytoalexin などが注目される。

罹病性品種の被侵入細胞では特に目立つた変質が起 こらない原因については，直接的な証明は見当たらな い。高橋 ${ }^{133}$ は葉鞘裏面表皮にガラス針で傷をつけると 菌が侵入した場合と類似した变質を起こすが，附傷と 同時に感受性病斑の汗液を与えると变質が抑えられる ことから, 感受性の感染場に拈いて変質を抑制する物 質が生産されることを推察した。富山防) $2.4 \mathrm{DNP}$ 処理したジャガイモの中肋表皮では疫病菌侵入による 細胞の褐変が遅れることを報告している。扣そらく罹 病的な場合では玉利 ${ }^{15)}$ の報じたように菌侵入の刺戟な いしは菌の分泌する物質によつて細胞内に呼吸の高ま りと連関した代謝の高まりが括こらないことが変質, 褐変を伴わない原因と考えられるが，これらの点は race を異にする菌株を用いて改めて検討したい。

一般に抵抗性とされている品種でも病原力の強い菌
株を接種すれば単に侵入菌糸の伸展度が増大するだけ でなく, 被侵入細胞あるいはその隣接細胞の生死並び に TTC 還元作用, nadi 試薬执よび phloroglucine$\mathrm{HCl}$ による呈色反応等の諸反応が一般に罹病性とされ ている品種の示すそれらの反応ときわめて類似する。 この事実は用いた品種, 菌株の範囲内においては抵抗 反応あるいは翟病反応は品種に固定的なるのではな く, 寄主の抵抗性と菌株の病原力との相対的な関係に よつて決定され，かつそこに現われる諸反応はすくな くとも現象的には全く共通的なるのであることを示 す。これらについては更に品種抵抗反応の逆転を伴う ような菌型を供試して追試してみたい。

\section{6. 摘 要}

荔支江（抵抗性）执よび愛知旭（罹病性）にいもち 病菌 (P2 菌) を葉鞘接種し, 寄主細胞並びに侵入菌糸 の生死を経時的に観察した。また上記品種に病原力の 異なる菌株（P2 菌および 53-33 菌）を接種した場合 の寄主細胞の生死, 寄主組織の TTC 還元作用, nadi 試薬による呈色反応, phloroglucine-HCl による呈色 反応の変動を調べた。

荔支江でも愛知旭でも接種後 12 時間目には侵入が みられたが，この時期までは両品種とも被侵入細胞は 生きていた。接種後 18 時間目以降荔支江では被侵入 細胞はほとんど死んだが，愛知旭では菌糸がある程度 伸長して子細胞は生きて和り，被侵入細胞の死は遅延 した。隣接細胞の死は接種後 24 時間目までは荔支江 に多かつたが，44 時間目には愛知旭で多かつた。

荔支江では被侵入細胞内での菌糸の死は寄主細胞の 死よりやや遅れるようにみられた。

荔支江でも病原力の強い53-33 菌を接種すると奇 主細胞の死は遅延し, 寄主組織の TTC 還元作用, nadi 試薬执よび phloroglucine-HClによる呈色反応は 罹病性品種に打けるそれらの反応と類似した。また愛 知旭に同菌を接種した場合，被侵入細胞の死，隣接細 胞の死は P2 菌を接種した場合よりも更に遅延した。

(1962. 5. 29 受理)

\section{引用交献}

1. 鐙谷大節 (1959). 東北農試研報 $17: 1-101$.

2. 相見霊三 (1953). 細胞生理実験法. 東京, pp. 296.

3. 後藤和夫 · 大畑貫一 (1957). 日植病報 22 (1) : 12 .

4. 後藤和夫 - 山中 達 (1961). 病害虫発生予察特 別報告 $5: 5-22$. 
5. 鋳方末彦・松浦 義・田口重良 (1931). 農事改 良資料 $20: 1-140$.

6. 伊藤誠哉・坂本正幸 (1941). 農林省委託 稲熱病 に関する研究。昭和 15 年度報告, 1-30.

7. 河村栄吉・小野小三郎 (1948). 農試査報 4 (1) : 13-22.

8. Lison, L. (今泉正訳, 1954). 組織化学括よび細 胞化学. 東京. pp. 532 .

9. 坂本正幸 (1949). 東北大農研壹報 1 (3) : 120129.

10. 鈴木直治・土居養二・豊田 栄 (1953). 日植病 報 17 (2) : 97-101.
11. 鈴木直治 (1957) ・ 農研報告 C 8 : 69-132.

12. 高橋喜夫 (1951). 北海道立農試報 $3: 1-61$.

13. 高橋喜夫 (1955). 杤内 - 福士還暦記念論文集, 245-248.

14. 玉利勤治郎 (1959). 新潟大農学術報告 11: 121 -140 .

15.玉利勤治郎 (1960)。蛋白核酸酵素 5 (12) : 664 -676 .

16. 富樫邦彦 - 小笠原長宏 - 玉利勤治郎 (1960). 日 植病報 25 (3) : 142-147.

17. 富山宏平 (1957). 日植病報 22 (2) : 75-78.

18. 植原一雄 (1958). 日植病報 23 (3) : 127-130.

\section{Summary}

This paper deals with the host-parasite interaction in the rice blast disease, using the following four combinations of two races and two rice varieties:

isolate P2 (race N) $\times$ Reishiko $\cdots \cdot$.resistant isolate 53-33 (race C) $\times$ Reishiko $\cdots$ susceptible

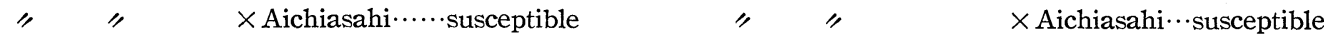

Inner surface of detached leaf-sheath was inoculated with dilute spore suspension and the reaction of invaded cells was examined under microscope, after 12 to 44 hour-incubation at $26^{\circ} \mathrm{C}$. The infected tissue was soaked in $0.8 \mathrm{M} \mathrm{KNO} 3$ solution prior to the examination in order to test for the plasmolytic activity of the invaded and the neighbouring cells.

1. Hyphae of $\mathbf{P} 2$ penetrate the cell wall of both varieties within 12 hours after inoculation. All the invaded cells are alive until this time (Plate I). After 18 hours, however, most of the primarily invaded cells of the resistant variety (Reishiko) appear to have died, whereas, most of those of the susceptible variety (Aichiasahi) remain alive. A similar tendency was traced during the later period, from 24 to 44 hours after inoculation (Plate I). In the resistant variety, the hyphae enclosed in most of the invaded cells die within 24 hours after inoculation, whereas, in the susceptible variety, they remain alive in most of the invaded cells for much longer period (Plate II). Cells adjoining the primarily invaded cell appear to have died more abundantly in the resistant variety than in the susceptible variety within 24 hours after inoculation, but the number of dead cells around the invaded cell tend to increase rapidly in the susceptible variety during the later period until about 44 hours.

2. When the variety Reishiko is inoculated with the isolate $53-33$, which is highly virulent to both varieties, the death of primarily invaded cells is markedly delayed. This result is quite similar to that with Aichiasahi inoculated with P2. Similarities are also observed between Reishiko-53-33 and Aichiasahi-P2 combinations in color reactions of the invaded tissues to triphenyltetrazolium chloride, nadi-reagent, and phloroglucine-HCl.

3. From these results it is concluded that, although Piricularia oryzae is not an obligate, there must be a symbiotic phase in the early stage of infection, in case the host is susceptible, or that the hypersensitive reaction of the host is a main cause of resistance.

(National Institute of Agricultural Sciences, Nishigahara, Tokyo, Japan)

\section{Explanation of Plates}

Plate I. Photomicrograph showing varietal difference in plasmolysis of the primarily invaded 
cells and their neigbours of inner epidermis of rice leaf sheath at early stages of blast infection.

A 1. and R1, $12 \mathrm{hrs}$ after inoculation; No degeneration of cytoplasm.

$A$ 2. and $R 2,18 \mathrm{hrs}$ after inoculation; The primarily invaded cell of A2 shows plamolysis, while R2 shows only granulation of plasm.

A 3. and R3, $24 \mathrm{hrs}$ after inoculation; The primarily invaded cell of A3 shows hyphal branches and plasmolysis, while R3 shows only disorganization of plasm.

A 4. and R4, $44 \mathrm{hrs}$ after inoculation; The primarily invaded cell of A4 shows vigorous growth of hyphae but it does not show already an ability to plasmolyse, while R 4 is almost unchanged as compared to R3.

A, Aichiasahi (susceptible variety); R, Reishiko (resistant variety).

Plate II. Two successive pictures showing the growth of hyphae in the primarily invaded cells in two rice varieties Reishiko and Aichiasahi.

Left were pictured at $24 \mathrm{hrs}$ after inoculation without treatment for plasmolysis, and right at 44 hrs after inoculation, with treatment for plasmolysis.

1. Resistant host: No further growth of the intracellular hypha from the left picture to the right, but there is a rapid browning and granulation immediately after penetration.

2. Do: An extending hypha can be detected in a neighbour cell from the primarily invaded cell, which shows slight degeneration already at $24 \mathrm{hrs}$ after inoculation.

3. Susceptible variety: Any sign of degeneration has not been shown until $24 \mathrm{hrs}$ after inoculation (left), and a vigorous mycelial growth in the invaded cell in $44 \mathrm{hrs}$ (right).

4. Do: Any sign of degeneration has not been shown up to $24 \mathrm{hrs}$ after inoculation (left), and a vigorous mycelial growth in neighbour cells from the primarily invaded cell.

5. Do: Plasmolysis of an invaded cell in $24 \mathrm{hrs}$ after inoculation (left) as well as in 44 hrs after inoculation (right). This indicates evidently that the invaded cell of susceptible varieties is still alive until a certain period ( $24 \mathrm{hrs}$ in this experiment) after the invasion.

$12 \mathrm{hrs}$ after inioculation $\quad 18 \mathrm{hrs}$ after inoculation $24 \mathrm{hrs}$ after inoculation $44 \mathrm{hrs}$ after inoculation

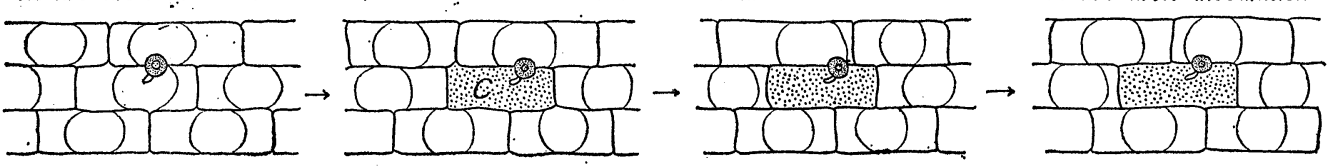

Reishiko
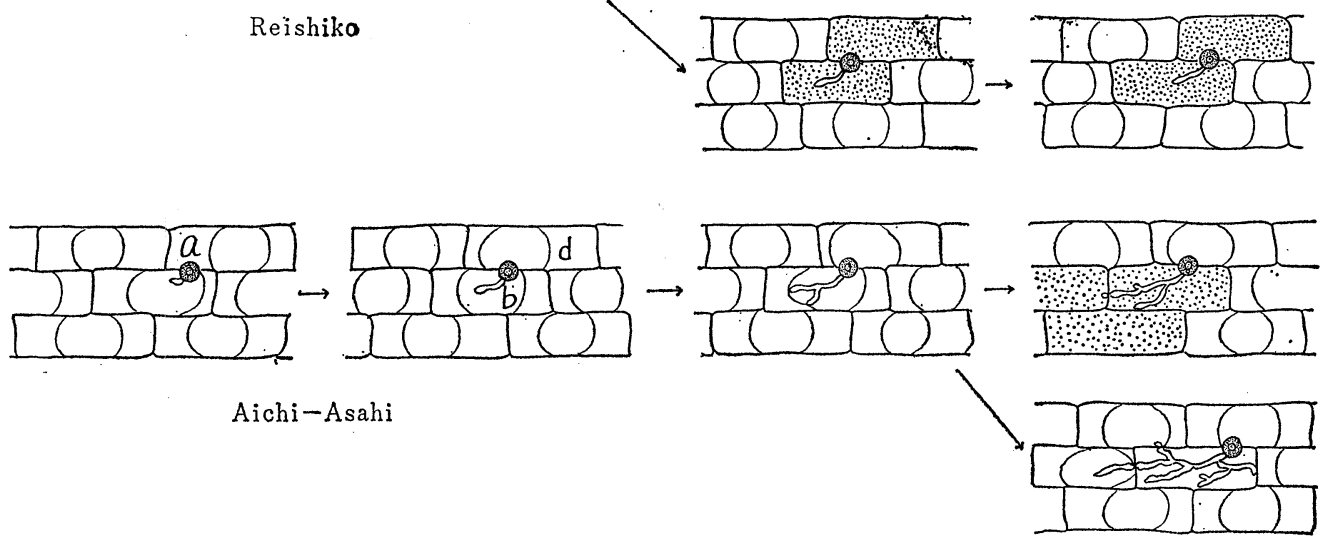

Fig. 1. Diagramatic illustrations, showing varietal difference in plasmolysis of the primarily invaded cells and their neighbours of inner epidermis of rice leaf-sheath at early stages of blast infection. Reishiko, resistant to P2; Aichiasahi, susceptible to P2; a, appressoria; b, intracellular hyphae; c, degenerated cells; and d, plasmolysed cells with dwingled cytoplasm. 


\section{Plate I}

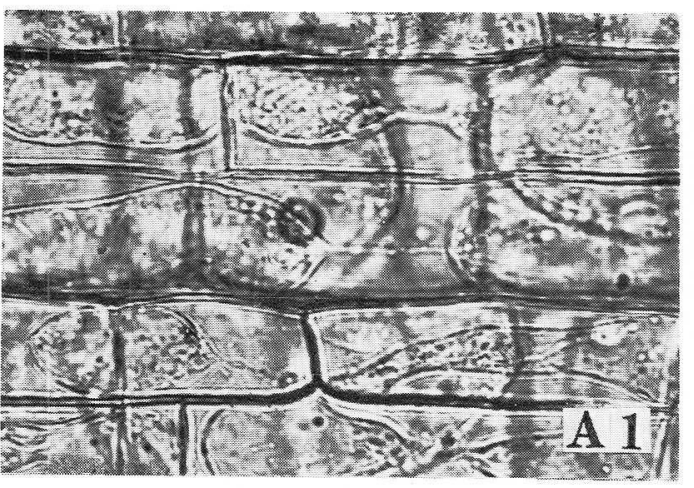

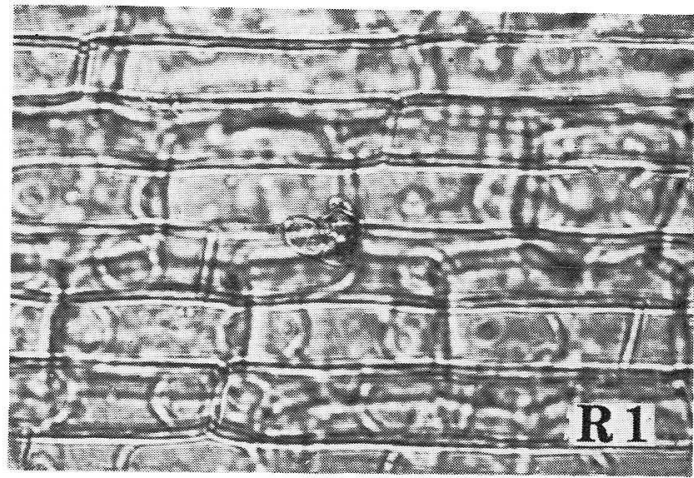
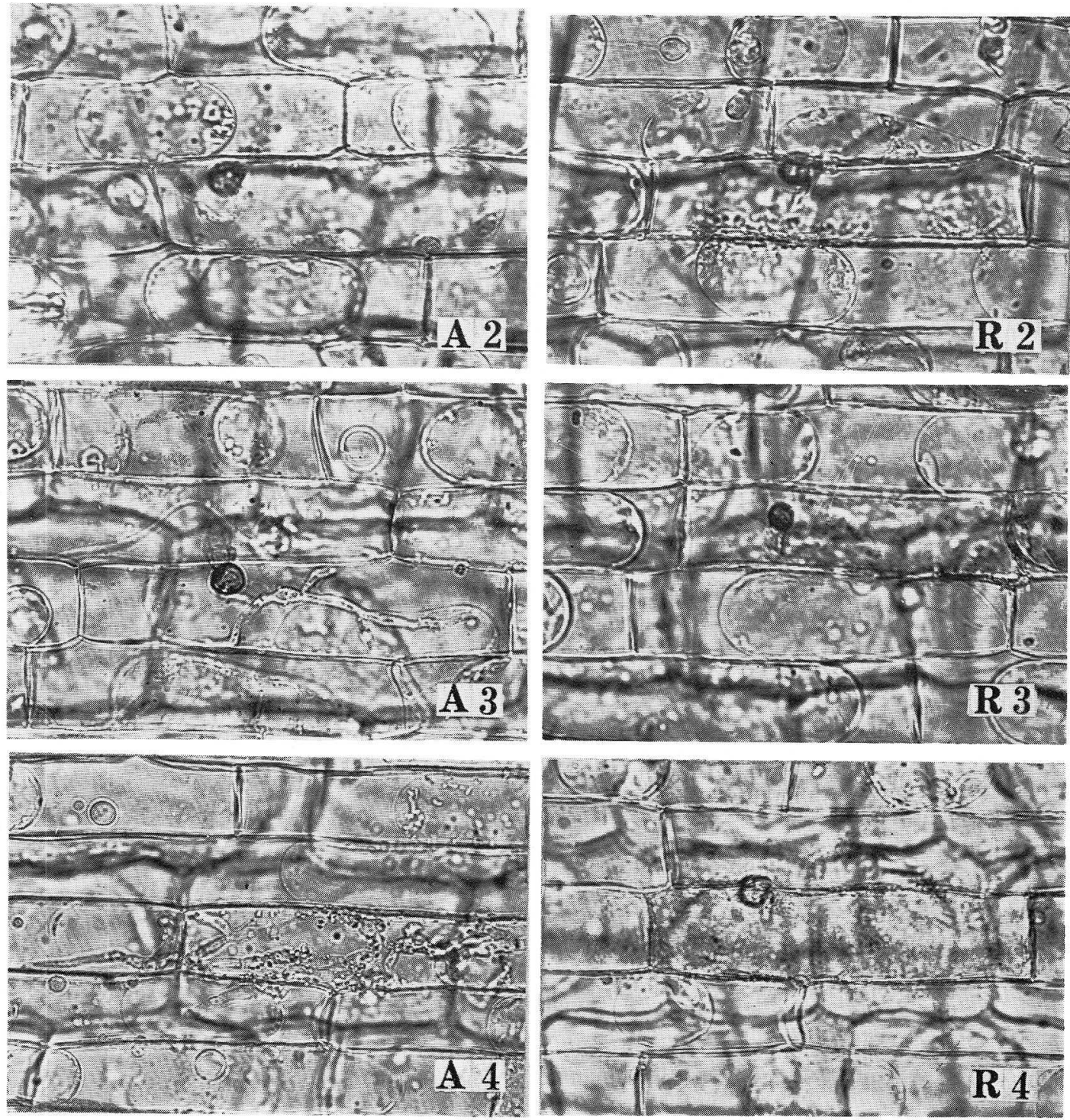


\section{Plate II}
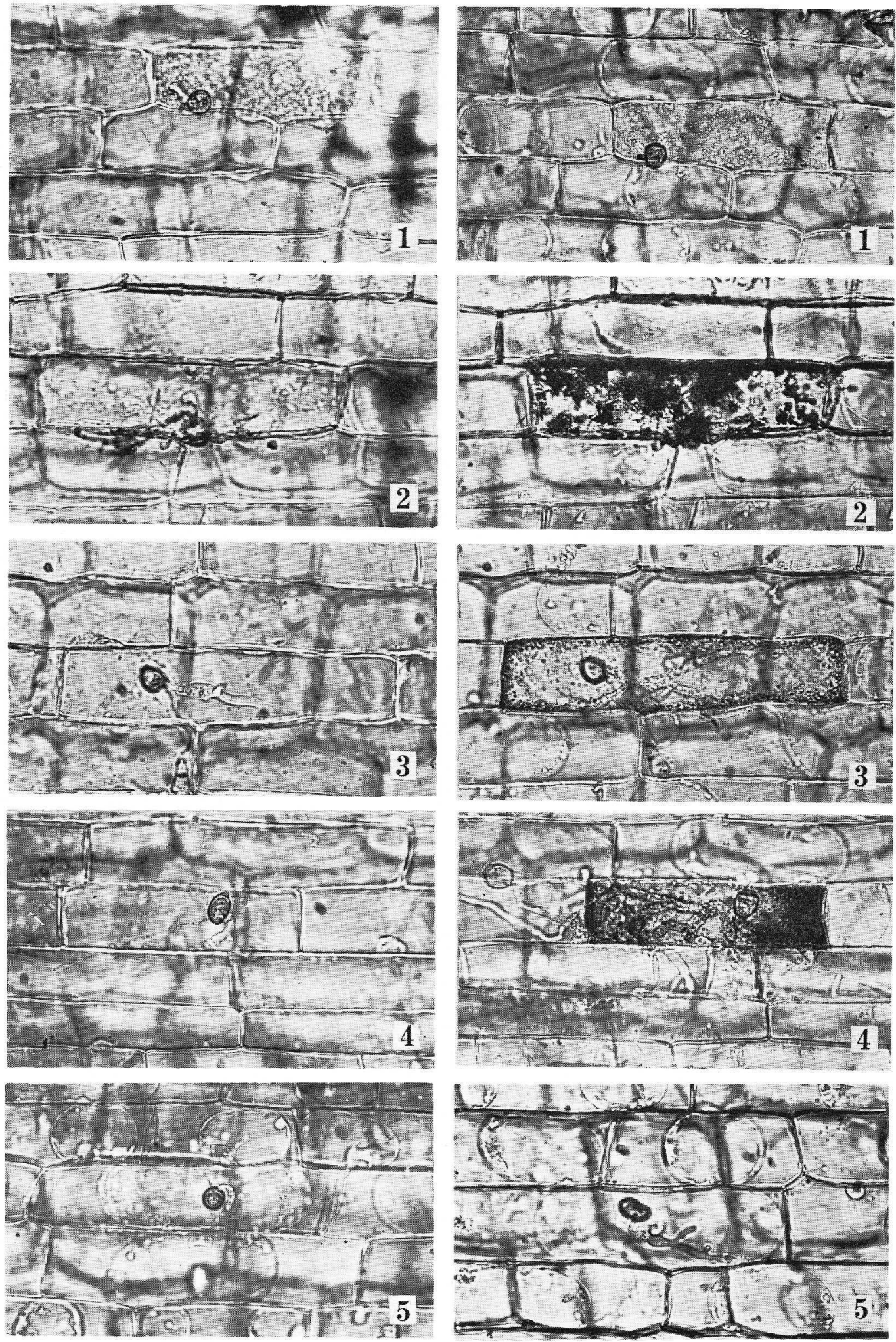